\title{
Using History to Make History? Progressive Farm Organizing During the Farm Revolt of the 1980s
}

\author{
William C. PRATT
}

Life here has been incredible since January 2 . I knew by noon that day that we were in a very different phase of our work, and that the farm movement had indeed arrived in full force. Since then, we have been working intensely and almost without let-up - literally seven days a week. We've never experienced anything quite like it. Public protests have been rolling across the countryside since the 3rd of January, when we organized the year's first foreclosure protest in Nevada, Iowa. They have been going on across the state ever since, with the big victory coming on January 30 when we took over 200 farmers and union members to Chariton and shut down a machinery sale cold. It was a tremendous victory for us ... and for the movement. We pulled out all the stops on that sale, and got tremendous press coverage nationally. There is still no letup as we go into mid-March, and we don't really anticipate much of a break until summer. ${ }^{1}$

THESE WORDS do not date from the 1930s; they are not observations from the Farmers' Holiday era. They were written during the 1980s, a decade that may have witnessed more rural protest than any other since the 1930s. This was not a case of

An earlier version of this essay was presented at the Northern Great Plains History Conference, St. Paul, Minnesota, 30 September 1994.

1. [David Ostendorf] to Jessica [Lange], 12 March 1985, David Ostendorf Papers, Iowa State University, Ames, Iowa. Ellipses in original.

THE ANNALS OF IOWA 55 (Winter 1996). OThe State Historical Society of Iowa, 1996. 
history repeating itself, however, even though activists frequently turned to the historical record for inspiration and ideas.

The farm revolt of the 1980s is a more complex topic than might first be imagined. At one point, the New York Times estimated that between 100 and 150 new farm groups had emerged in the first half of the decade, and "virtually all" of them "describe[d] themselves as 'populist."' 2 This essay examines organizational approaches used by progressive or left-of-center midwestern farm activists in those years. Many of these people had Iowa connections and they were involved with such groups as the U.S. Farmers Association, the Iowa Farm Unity Coalition, PrairieFire, the North American Farm Alliance, and the League of Rural Voters. ${ }^{3}$ This essay is not offered as a comprehensive

2. Keith Schneider, "Farm Groups Seen Affecting 1986 Elections," New York Times, 5 January 1986. (Many of the newspaper articles cited in this essay are from the clippings collection at the PrairieFire office in Des Moines, Iowa.) See also Harry C. Boyte, Heather Booth, and Steve Max, Citizen Action and the New American Populism (Philadelphia, 1986), 133-45; Jim Schwab, Raising Less Corn and More Hell: Midwestern Farmers Speak Out (Urbana, IL, 1988); William P. Browne, Private Interests, Public Policy, and American Agriculture (Lawrence, KS, 1988); Mark Friedberger, Shake-Out: lowa Farm Families in the 1980s (Lexington, KY, 1989); William P. Browne, "Challenging Industrialization: The Rekindling of Agrarian Protest in a Modern Agriculture, 1977-1987," Studies in American Political Development 7 (1993), 1-34; Patrick H. Mooney and Theo J. Majka, Farmers' and Farm Workers' Movements: Social Protest in American Agriculture (New York, 1995), 97-119.

3. I have chosen the term progressive to characterize left-of-center farm activists in the 1980s, who often characterized themselves in this way. Part of the explanation for this usage probably was tactical; progressive had a more positive connotation among the general public than did radical, leftist, or left-wing. (In mid-1989, the New York Times referred to PrairieFire as a "left-leaning farm advocacy group." When the organization objected, the paper subsequently noted that "PrairieFire provides education and economic and legal support to family farms and rural communities. It describes its politics as 'progressive."' "Editors' Note," New York Times, 26 June 1989.) Progressive is at least as appropriate as any other term to label the specific proposals farm activists advanced in this era, and certainly more so than populist, a term applied so broadly today that it is virtually meaningless unless accompanied by a particular definition. See note 16 . Some observers, including Friedberger and Browne, have used neo-populist to characterize the positions of left-of-center farm activists. That usage seems more acceptable in that this term has not been applied indiscriminately. The individual political sympathies of the rank-and-file of these groups were quite varied, and observers need to be careful not to assume otherwise. See Browne, Interests, Public Policy, and American Agriculture, 83. 
study of such efforts, but rather as an exploration of some of the themes of progressive rural activism during the 1980s. Farm activists in this era often identified with earlier insurgencies and borrowed some of their tactics; at the same time, they shared newer techniques with other contemporary social causes such as the civil rights and environmental movements. The people and groups discussed in this essay played a major role in the farm revolt of the $1980 \mathrm{~s}$. Their efforts frequently attracted media attention and they met with at least partial success on a number of occasions. They learned from the past, but were not dominated by it. As a result, they made a noteworthy addition to the history of progressive farm organizing.

AN IMPORTANT PART of the background of recent farm insurgencies was the relative lack of response of well-established farm groups such as the National Farmers Union (NFU) and the National Farmers Organization (NFO). ${ }^{4}$ As a result, the American Agriculture Movement (AAM) emerged in the late 1970s. AAM-sponsored tractorcades to Washington and a number of state capitals were dramatic, but internal disunity and lack of a coherent program soon undercut the new group. Although the AAM unofficially backed Ronald Reagan in the 1980 election, members grew disenchanted with his administration's handling of the deepening agricultural crisis. AAM played a part in the farm insurgency of the 1980s, yet the organization of many smaller groups such as the Iowa Farm Unity Coalition or Minnesota's Groundswell indicates that AAM's appeal had declined. AAM split into two separate organizations in the early 1980s and had to share the stage with many other groups. ${ }^{5}$

4. For background on the NFU and NFO, see John A. Crampton, The National Farmers Union: Ideology of a Pressure Group (Lincoln, NE, 1965); Lowell K. Dyson, Farmers' Organizations (Westport, CT, 1986), 206-32.

5. Allan J. Cigler and John Mark Hansen, "Group Formation Through Protest: The American Agriculture Movement," in Allan J. Cigler and Burdett A. Loomis, eds., Interest Group Politics (Washington, DC, 1983), 84-109; William $P$. Browne and John Dinse, "The Emergence of the American Agriculture Movement, 1977-1979," Great Plains Quarterly 5 (1985), 221-35; Dyson, Farmers' Organizations, 8-14. Many farmers from AAM participated in groups such as the Iowa Farm Unity Coalition or Groundswell. See Browne, Private Interests, Public Policy, and American Agriculture, 72. 
During the 1980s organizers on the left and right struggled to win the allegiance of the distressed family farmer. AAM, at least in some respects, represented farmers in motion rather than in a movement, and competing groups with a message sought to win over the rural population. When the farm crisis worsened in the 1980s, the stakes were raised. One of the big stories of the decade was the growth of right-wing extremism in the countryside. Although the Posse Comitatus attracted the most attention, many promoters of conspiracy theories, antiSemitism, and other mean-spirited notions found fertile soil for their ideas in rural America. ${ }^{6}$ Yet there also was a major effort to counter these tendencies and shift the farm uprising to the left.

The left had suffered serious setbacks among American farmers after World War II, but a remnant of the agrarian left survived the Cold War. Its organizational center was the small U.S. Farmers Association (USFA). The USFA had an office in Hampton, Iowa, and published a monthly newspaper, U.S. Farm News. Fred Stover had headed the USFA since its formation in the 1950s. Eighty-two years old in 1980, he had a long record of backing left-wing causes. He had supported Henry A. Wallace's 1948 presidential campaign and opposed the Korean War. Formerly affiliated with the NFU, Stover's group was kicked out of the liberal farm organization because of his politics. The USFA slogan of "peace and parity" on the masthead of the U.S. Farm News was amended in the late 1960s to include "and power to the people." Unlike other farm groups in the United States, the USFA publicly opposed the Vietnam War. Stover himself was an effective speaker and began appearing on college campuses. As a result, he and the USFA attracted attention in antiwar circles. Some young activists

6. See Daniel Levitas and Leonard Zeskind, "The Farm Crisis and the Radical Right," in Renew the Spirit of My People: A Handbook for the Ministry in Times of Rural Crisis (Des Moines, 1987), 23-30; James Corcoran, Bitter Harvest: Gordon Kahl and the Posse Comitatus: Murder in the Heartland (New York, 1991); Osha Gray Davidson, Broken Heartland: The Rise of America's Rural Ghetto (New York, 1991), 101-23; James Coates, Armed and Dangerous: The Rise of the Survivalist Right (New York, 1995), 104-156. 
joined Stover's group over the next decade, and several of them played a central role in the farm revolt of the $1980 \mathrm{~s}^{7}$

The younger people were impressed with the old-timers they met at the annual USFA meeting. These individuals included veterans of the Nonpartisan League, the Socialist and Communist parties, the 1948 Wallace campaign and, of course, the Farmers' Holiday of the 1930s. In early 1980, a few young activists planned a symposium at Iowa State University on the historic roots of agrarian protest. The three-day affair featured panels of historians, veterans of past rural struggles, contemporary farm activists, poets such as Meridel LeSueur and Don West, and films such as "Northern Lights."

The symposium was part of a strategy to activate a progressive farm movement. Dating to the late 1970s, the young people and Merle Hansen, a USFA vice-president, sought to remake the Farmers' Association into a force within the ranks of organized agriculture. They failed to achieve long-lasting results, but as a result of their efforts, the USFA became deeply involved for a time in the insurgency that developed in the 1980s. ${ }^{9}$ The young activists, including Dixon Terry, George Naylor, Mark Ritchie, and Dale Wiehoff, helped to organize farm coalitions in several states in 1982. Along with Merle Hansen, they also played a key role in the formation of the North American Farm Alliance (NAFA), a coalition of U.S. and Canadian groups. Other figures, such as Tom Quinn of the

7. Dyson, Farmers' Organizations, 345-48; William C. Pratt, "The Farmers Union, McCarthyism, and the Demise of the Agrarian Left," The Historian 58 (1996), 329-42; William C. Pratt, "When the Old Agrarian Left Meets the New: Fred Stover and the U.S. Farmers Association, 1959-1990" (paper read at the Organization of American Historians Annual Meeting, Atlanta, Georgia, 14 April 1994). I attended the USFA's annual convention from 1972 to 1986.

8. Ann Toner, "Nebraskans Will Talk About Parallels Today to Farm Protests of Past," Lincoln Star, 21 March 1980; Don Muhm, "Agrarian Protest: Its Place in U.S. History," Des Moines Register, 25 March 1980; New York Times, 30 March 1980.

9. Pratt, "When the Old Agrarian Left Meets the New." Hansen (born in 1919) farmed in northeast Nebraska. He was a long-time associate of Fred Stover and had worked for the Iowa Farmer's Union in the early 1950s. For a recent interview with Hansen, see Studs Terkel, Coming of Age: The Story of Our Century by Those Who've Lived It (New York, 1995), 124-30. 
Wisconsin Farm Unity Alliance, Carol Hodne of NAFA, and Denise O'Brien of the Iowa Farm Unity Coalition also had a USFA connection for a time. The USFA "platform" or "launching pad" played an important, perhaps indispensable, role in the progressive rural insurgency of the $1980 \mathrm{~s}^{10}$

There were other important organizations in Iowa as well. Rural America, a liberal rural advocacy group, opened a Midwest office in Des Moines in the summer of 1981. When David Ostendorf, a United Church of Christ minister, arrived in Iowa to head the Rural America office, he had little idea that he would devote the remainder of the decade to working on farm crisis issues. He soon was joined at the office by a young intern from the University of Michigan, Danny Levitas, who also played a key role in the new farm movement. ${ }^{11}$

10. David Ostendorf, interview with author, Des Moines, IA, 25 February 1994; Merle Hansen, telephone interview with author, 7 March 1994; Mark Ritchie, telephone interview with author, 24 March 1994; Dale Wiehoff, telephone interview with author, 25 March 1994. For early treatment of NAFA, see Dyson, Farmers' Organizations, 269-71. USFA involvement in the farm revolt of the 1980s, however, subsequently declined. USFA activity had been due largely to the work of Dixon Terry, Merle Hansen, George Naylor, and other young activists. Their efforts provoked controversy within the organization, however, and they fell out with Stover over the direction of the USFA. At the 1985 annual meeting, neither Terry and Hansen were reelected to the Farmers' Association board. That action essentially marked the end of USFA involvement in the farm revolt. The split between Stover and Terry, Hansen, and Naylor was a painful one, as the three younger men had been close to Stover previously and had seen him as their mentor. Pratt, "When the Old Agrarian Left Meets the New."

11. Ostendorf interview; Daniel Levitas, telephone interview with author, 24 March 1994. Ostendorf's first contact with USFA people may have come through a small group in southwest Iowa called the Progressive Prairie Alliance (PPA). Dixon Terry, who farmed near Greenfield in Adair County, was one of the organizers of the PPA, a group that addressed foreign policy questions such as U.S. involvement in Central America as well as domestic issues. The PPA was a very small organization whose membership included both farmers and townspeople. In 1981, it hosted a showing of "Northern Lights" in Greenfield for a large group of cyclists, and Ostendorf was invited to see the film as well. Later, he spoke to a PPA meeting. I believe that both he and Levitas attended the USFA convention that fall. Dixon [Terry] to Fred [Stover], 25 March 1981 and 27 September 1981, Fred Stover Personal Papers (temporarily in author's possession); Daniel Levitas, "Progressive Prairie Alliance Tackles Iowa," Rural America 7 (January-February 1982), 6. 
In the fall of 1981 the USFA became more involved in the farm crisis. Members approved an activist program at the annual meeting, and the USFA obtained matching funds to hire Mark Ritchie to coordinate activities. As a result of this initiative, contacts with people in other organizations were further cultivated. USFA activists sought to work with other groups while advancing their own agenda on farm issues. ${ }^{12}$

The Iowa Farm Unity Coalition was organized in late January 1982. USFA activists called a meeting at a bank in Atlantic, Iowa, on a Saturday afternoon to discuss common concerns among agrarian activists. Approximately fifty people attended, most of them AAM, NFO, NFU, or USFA members. Although Curt Sorteberg, the Iowa FU's only staff person, played an active role, as did Rural America's David Ostendorf, USFA figures orchestrated much of the meeting, and USFA activist Dixon Terry emerged as a spokesman. The Coalition prepared a press release and made plans to protest President Ronald Reagan's upcoming visit to Des Moines. Members also made tentative plans to run a candidate for state secretary of agriculture. ${ }^{13}$ At the time of the meeting, none of these farm groups had a significant political presence on their own in Iowa. As a coalition, however, the groups had a real opportunity - in the short term, at least to reach a larger constituency of Iowa farmers and perhaps even wean some away from the Farm Bureau. Its organizers were heartened by farmers' involvement in the anti-Reagan protest two weeks later, and the Coalition soon attracted media attention. ${ }^{14}$ The Iowa Farm Unity Coalition would become one of the best known groups in the farm revolt of the $1980 \mathrm{~s}^{15}$

12. Pratt, "When the Old Agrarian Left Meets the New."

13. David Ostendorf, "Farm Unity Movement Grows in Iowa," Rural America 7 (Spring 1982), 5. I attended the Atlantic meeting. The NFU had organized a new Iowa affiliate after withdrawing the charter from Stover's group in 1954. This is the Iowa FU organization referred to here and in the remainder of the essay.

14. For the anti-Reagan demonstration, see Des Moines Register, 10 February 1982.

15. For a good overview of the Iowa Farm Unity Coalition, see Jerry Perkins, "Battle Cry of 'Unity' Sweeps like Prairie Fire for Desperate Farmers," Des Moines Register, 15 April 1984. 
MANY OF THE NEW GROUPS that emerged in this era assumed a "populist" identity. ${ }^{16}$ They thrived on the sentiments attributed to Mary Elizabeth Lease: "Farmers should raise less corn and more hell. ${ }^{17}$ Some activists consciously sought to connect their efforts with those of earlier rural insurgencies and studied the history of farm protest, seeking ideas and tactics as well as inspiration. As a practical matter, they learned more usable techniques from the Farmers' Holiday of the 1930s than from the Populism of the 1890s. ${ }^{18}$ One tactic from the 1930s that had particular appeal was the "penny auction." Here, protesters interfered with scheduled farm sales either by preventing the sale from taking place or by discouraging all but nominal bids on the items being auctioned off. ${ }^{19}$

The first penny auction of the 1980s may have taken place outside Westbrook, Minnesota, in August 1982. A Minnesota group, Citizens Organizations Acting Together (COACT) arranged the demonstration, although members from other organ-

16. Schneider, "Farm Groups Seen Affecting 1986 Elections," New York Times, 5 January 1986. Populist terminology raises difficulties when it is used anytime after the $1890 \mathrm{~s}$. In recent times, the populist label is applied to virtually any grass-roots antiestablishment effort or individual who assumes the pose of an aggrieved outsider. Michael Kazin, in The Populist Persuasion: An American History (New York, 1995), defines populism as a style of political rhetoric rather than adherence to a particular political position or perspective. Although Kazin's treatment covers political developments through the 1992 presidential election, it makes no reference to recent progressive farm groups that saw themselves as descendants of the historic Populism of the 1890s.

17. It is not clear that Lease ever made this remark. See Edward T. James, "Less Corn, More Hell? A Knights of Labor Glimpse of Mary Elizabeth Lease," Labor History (Summer 1975), 408-9. For Lease's biography, see Dorothy Rose Blumberg, "Mary Elizabeth Lease, Populist Orator: A Profile," Kansas History 1 (1978), 3-15.

18. Ostendorf interview; Carol Hodne, interview with author, Irwin, IA, 5 March 1994. For the Farmers' Holiday Movement, see John Shover, Cornbelt Rebellion: The Farmers' Holiday Association (Urbana, IL, 1965); Lowell K. Dyson, "The Farm Holiday Movement" (Ph.D. diss., Columbia University, 1968); David Nass, ed., Holiday: Minnesotans Remember the Farmers' Holiday Association (Marshall, MN, 1984); William C. Pratt, "Rethinking the Farm Revolt of the 1930s," Great Plains Quarterly 8 (1988), 131-44.

19. Technically speaking, a "penny auction" occurred only when chattels were actually sold at a sale. In the 1980 s, however, the term often was applied to any situation, involving real property or chattels, in which protesters interfered with the proceedings. 
izations, including AAM, NFU, and NFO, took part. A spokesperson from COACT told a Wall Street Journal reporter that "the group has studied the Depression-era penny auctions and plans to mobilize farmers all over Minnesota whenever there are farm auctions or foreclosures. ${ }^{20}$ Carol Hodne, then a USFA staffer, told a Minnesota crowd a few months later that "we have much to learn from our heritage of the Farmers' Rebellions of the 1930s. Farmers' united actions led to state and Federal policies to stop foreclosures and implement parity pricing. Our history of successful protests in the '30's must be shared with today's farm families to give us models for action and hope for our future. ${ }^{21}$

Jim Gambone, a Minnesota filmmaker, produced a reenactment of a 1930s penny auction titled Foreclosure. Nebraska Public Television broadcast a ninety-minute documentary, Plowing Up a Storm, on the history of midwestern farm protest. Both of these films were shown at farm movement meetings in the $1980 \mathrm{~s}^{22}$ Another example of "looking backward" involved researching anti-moratorium laws of the 1930s; researchers hoped to implement them or perhaps use them as models for new legislation. ${ }^{23}$

20. Meg Cox, "Farmers Start Reviving Penny Auctions, A 1930s Tactic for Preventing Foreclosure," Wall Street Journal, 10 September 1982; John Flory, "Penny Auction Stops Foreclosure; Dramatizes Farm Crisis," Minnesota Leader, October/November 1982.

21. U.S. Farm News, November 1982.

22. Cox, "Farmers Start Reviving Penny Auctions," Wall Street Journal, 10 September 1982; Minnesota Leader, October/November 1982; Hodne interview. Foreclosure was filmed in Milan, which had been in the heart of Minnesota Farmers' Holiday activity in the early 1930s. The local newspaper editor was very interested in Gambone's project, and reprinted a number of articles on Holiday efforts in the area. J. M. [Jack Miller], "And an Exception," North Country Anvil no. 49 (1985), 22; Patrick Moore, telephone interview with author, 12 September 1994. (Moore had been editor of the Milan paper at the time of the making of Foreclosure.) Plowing Up a Storm opens with a 1983 episode in Kansas where protesters attempt to stop a sale. Merle Hansen and David Ostendorf are among the contemporary figures interviewed on-camera later in the program. Jessica Lange's 1984 feature-length film, Country, dealt with a fictionalized contemporary family facing foreclosure. Dave Ostendorf and Danny Levitas served as consultants on this film, which was shown at farm meetings as well.

23. Ostendorf interview. See Sarah M. Vogel, "The Law of Hard Times: Debtor and Farmer Relief Actions of the 1933 North Dakota Legislative Session," North Dakota Law Review 60 (1984), 489-513. 
Rural insurgents turned to the past for ideas and legitimacy. They wanted to publicize that farmers had protested before, and that those protests had helped. Many of the recruits to the new farm movement had not previously been sympathetic to labor unions or the activist causes of the 1960s. Through publicizing the history of farm protest, insurgent leaders legitimized tactics that proved helpful in the 1980s. ${ }^{24}$

Despite a conscious attempt to use such history, insurgents of this era also departed from earlier efforts. These departures are partially explained by changes in American society, including transformations in agriculture. Organizers, however, also learned useful lessons from the civil rights, antiwar, and other recent social movements. ${ }^{25}$ Initially, most rural activists in the 1980 s probably were more familiar with these causes than with the history of farm protest. Part of what ultimately emerged was a combination of experience drawn from more recent social movements with the example of earlier agrarian activism. Farm protest in the 1980 s is, therefore, a more complicated story than "populism revisited."

Among the departures from earlier rural causes were more effective use of media and modern fund-raising techniques. Between 1982 and 1988, the new movement enjoyed much more positive coverage than farm causes had received in decades. Television exposure was a key; activists learned to schedule protests and other events to get on the evening news. On one occasion, a local paper complimented the Iowa Farm Unity Coalition in this regard, saying it "deserve[d] an Oscar, or television equivalent, an Emmy, for its mastery of the media. Last week's vigil a[t] the USDA offices was a slick production, and as far as exposure of the continuing problem of farm

24. Ostendorf interview; Hodne interview. This legitimization of protest probably had its limits. Dolores Swoboda recounted that the arrest and retention of a key Groundswell leader during a protest had a chilling effect on other Groundswell supporters. Dolores Swoboda, telephone interview with author, 16 September 1994.

25. For changes in agriculture, see John L. Shover, First Majority-Last Minority: The Transforming of Rural Life in America (Dekalb, IL, 1980); Gilbert C. Fite, American Farmers: The New Minority (Bloomington, IN, 1984). 
credit, it got maximum results for the number of man-hours expended." 26

Fund-raising requires a special genius, and some of the activists were quite gifted at extracting money from private donors, church groups, and foundations. Occasionally, organizers undertook coordinated fund-raising efforts, and some individuals learned to cultivate foundations and other donors interested in social justice issues. Perhaps the largest single source of funding for the 1980s farm movement was Willie Nelson's Farm Aid concerts. Rural activists such as Mark Ritchie, Dixon Terry, Dave Ostendorf, Carol Hodne, and Merle Hansen played key roles in determining how the proceeds of the initial concert should be distributed. ${ }^{27}$ National groups such as NAFA, PrairieFire, and the League of Rural Voters received $\$ 50,000$ each from the proceeds. In addition, some state groups, including the Iowa Farm Unity Coalition, received amounts ranging from $\$ 20,000$ to $\$ 25,000 .^{28}$ Although later concerts did not raise as much money, the combined contribution to PrairieFire and Iowa Farm Unity Coalition from Farm Aid I and II totalled $\$ 125,000$, while the Ames-based NAFA drew $\$ 97,500{ }^{29}$

26. Wendy L. Wall, "Farm Movement Is Attracting More Attention Than Any Agrarian Protest in Recent Decades," Wall Street Journal, 13 February 1985; Daniel Levitas, telephone interview, 24 March 1994; Adair County Free Press 2 April 1986 (source of quotation). Another weekly paper noted that it had not been advised of a local event: "Iowa television outlets and daily newspapers had been notified and were present in large numbers with cameras and reporters. The protest drew statewide and national television and newspapers. The protesters, however, neglected to inform the News-Review of the impending action." News-Review (Sigourney, Iowa), 23 January 1985. The rural insurgency of the 1980 s did a better job of attracting media coverage than its predecessors, but lowa novelist Jane Smiley recently told Mother Jones that "The last 20 years have seen the end of the family farm with hardly even a yelp from anyone in the media." Mother Jones 21 (January/February 1996), 48.

27. Ostendorf interview; Hodne interview; Becky Glass, telephone interview, 6 September 1994. Not all fund-raising efforts were successful, however. One county group in Minnesota lost $\$ 1200$ on a fund-raiser. Swoboda interview.

28. Hodne interview. In early 1985, the Midwest Rural America office became PrairieFire, an independent rural advocacy group with its own board of directors. It continued to staff the Iowa Farm Unity Coalition and maintained a high profile throughout the farm revolt of the 1980s.

29. Jerry Perkins, "Farm Aid Helping to Tune of Millions," Des Moines Register, 30 July 1987; Farm Aid, Inc. Report (Cambridge, MA, [1987]). 
The farm movement of the 1980 s was involved in more than protest. A large part of its activity was devoted to counseling and legal action. For example, the Iowa Farm Unity Coalition and other groups established hotlines to deal with a variety of problems. In many cases, callers sought help to fend off foreclosure or "voluntary" settlements forced by U.S. government agencies such as the Farmers Home Administration (FmHA) or the Production Credit Association. Danny Levitas and a number of others who provided this type of counseling became experts on agency regulations. Some counseling provided practical advice on obtaining food stamps or other kinds of public assistance. In addition, counselors dealt with the human cost of the farm crisis, talking to farmers suffering from stress and emotional disorders. Suicides in the countryside increased in the 1980 s, and some hotlines dealt with suicide prevention. Counseling by phone or in person was an ongoing activity for many rural groups in this era. ${ }^{30}$

Legal action was another important part of the new farm movement. There was an avalanche of complaints about the FmHA in the early and mid-1980s. Ironically, the FmHA was the successor to the Farm Security Administration, a New Deal agency designed to help small farmers and serve as "the lender of last resort." Now, however, it threatened to foreclose on thousands of hard-pressed borrowers. Farm groups and farmers filed a number of lawsuits against the FmHA, but perhaps the most celebrated effort was Coleman $v$. Block, a class action suit brought by Sarah Vogel in North Dakota. In May 1983, a federal judge issued an injunction in the case that required the FmHA to grant borrowers certain procedural rights prior to initiating foreclosure proceedings or other actions. ${ }^{31}$ Elsewhere, similar efforts to tame

30. See Wallace's Farmer, 9 July 1983; Friedberger, Shake-Out, 71-75.

31. James T. Massey, "The Coleman Decision: What Does it Mean for You?" North American Farmer, 26 July 1984; "Farmers in Crisis: A Challenge to Legal Services," Clearinghouse Review 18 (November 1984): 704-33; Sarah Vogel, interview with author, Bismarck, ND, 4 August 1994. Vogel was elected state commissioner of agriculture in 1988 and reelected in 1992. She was the first woman elected to that post in the United States. Curt Stofferahn, "Farm Advocate Elected Ag Commissioner," North American Farmer, December 1988. She recently announced that she would not seek a third term. 
the FmHA were under way. Jim Massey, who had served as co-counsel in the North Dakota case, later founded the Farmers Legal Action Group (FLAG), which became involved in numerous lawsuits against federal credit agencies. ${ }^{32}$ Counseling and legal action may seem a far cry from the activities of Mary Elizabeth Lease, A. C. Townley, or Milo Reno, but they were an important part of the farm movement of the 1980s.

FARM PROTEST has always had a political agenda, and the rural efforts of the 1980 s were no exception. Unlike the 1890 s or the World War I era, however, farmers did not organize new political movements such as the People's Party or the Nonpartisan League. There were not as many farmers in the 1980s, and their possibilities, like their numbers, were more limited. Regardless of their individual political beliefs, rural activists felt compelled to line up with Democrats (or at least some Democrats) during the farm crisis of the 1980s. It was an article of faith for many of them that price was the key to farm prosperity, and that farm prices were set in Washington. ${ }^{33}$ To effect change, then, farmers had to oust Reagan and regain Democratic control of the U.S. Senate. Farm activists worked hard to elect Tom Harkin in Iowa and Paul Simon in Illinois in 1984. As a result, Harkin and the Iowa Farm Unity Coalition enjoyed a close relationship.

Iowa plays a crucial role in presidential politics due to its early caucuses. Presidential contenders come to Iowa early and often. In 1983, for example, Gary Hart turned up at the USFA annual convention in Mason City. He was quickly introduced to the views of young activists, including their rejection of exports as a solution to the problems of U.S. agriculture. ${ }^{34}$ Dixon

32. Vogel interview. At the time of the North Dakota suit, Massey worked with Mid-Minnesota Legal Assistance. By mid-1987, FLAG had received \$250,000 from Farm Aid. Farm Aid, Inc. Report, 16.

33. Some also tried to persuade state legislatures to pass minimum price bills.

34. I attended this USFA meeting. At one point, Hart indicated that he had never heard of farmers who didn't like exports before. (At least one person had raised concerns that U.S. exports might ruin third-world farmers.) After the public session, George Naylor, Dixon Terry, and one other individual met privately with Hart and briefed him on their views on U.S. agricultural policy. 
Terry later was chosen as a Hart delegate to the 1984 Democratic convention, where he and other farm activists organized a rural caucus. There, he was joined by Merle Hansen, who delivered one of the seconding speeches for Jesse Jackson. ${ }^{35}$

Ultimately, Jackson turned out to be the best political friend that the 1980s insurgents had. In 1983 he traveled to western Kansas to speak to a crowd of farmers, and he repeatedly showed up for demonstrations and protests over the next several years. He launched his 1988 bid for the Democratic nomination in Greenfield, Iowa, and was photographed milking a cow in Dixon Terry's dairy barn. ${ }^{36}$ No other supporter, including Willie Nelson, had more national visibility.

The Internal Revenue Service Code restricts the political activities of nonprofit corporations, so groups such as PrairieFire and NAFA walked a thin line when it came to political action. In 1984, when the League of Rural Voters was organized, activists hoped to mobilize the rural vote on particular farm issues rather than backing specific candidates. Although the League had a midwestern presence and played a supporting role in the 1984 and 1988 elections, its organizers were already involved in the farm movement and simply were taking on another assignment. For example, Dixon Terry initially headed the League in Iowa and later became its national cochairman. ${ }^{37}$

Farm activists also were involved in lobbying efforts for state and national legislation, including the so-called Harkin Bill,

35. Niel Ritchie, "Rural Caucus Pushing Democrats to Address Farm Crisis," North American Farmer, 26 July 1984.

36. Telephone interview with Merle Hansen, 7 March 1994; Hodne interview; William Robbins, "Jackson Leads Peaceful Protest of Farm Foreclosure," New York Times, 9 April 1985; Merle Hansen, "Jackson Still Our Best Bet," North American Farmer, December 1988. Jackson spoke at Terry's funeral after he was struck down by lightning in 1989. Ken Pins, "Jackson Leads Tribute to Terry, Farm Activist," Des Moines Register, 2 June 1989.

37. Jerry Perkins, "Dixon Terry: At Home in Milk House, Statehouse," Des Moines Register, 22 February 1987. Terry was a major figure in the progressive farm movement of the 1980s. In 1984, Esquire magazine named Terry and his wife to its list of "The Best of the New Generation: Men and Women Under Forty Who Are Changing America." See Stephen Wright, "Digging In: Iowa Farmers Linda and Dixon Terry Fight for the Good Earth," Esquire (December 1984), 508-15. 
which some of them reportedly had helped write. The National Save the Family Farm Coalition, organized in 1986 to promote this legislation, included the Iowa Farm Unity Coalition, NAFA, and other new organizations. But the multiplicity of farm groups in the 1980 s also meant additional competition for members and funding. Some, like NAFA, were unable to maintain a niche for their activities. ${ }^{38}$

COALITIONS ARE APPEALING because they promise to strengthen the numbers of smaller groups, while permitting each organization to maintain its separate identity. But they can also present some very real practical problems. The Iowa Farm Unity Coalition initially was staffed on a day-to-day basis by Curt Sorteberg of the FU and the Midwest Rural America office. After Sorteberg was laid off by the FU, Rural America and its successor, PrairieFire, assumed the staffing responsibility. This arrangement, necessary as it might have been, meant that the Coalition depended heavily on the services of another group which was not itself a farm organization. (This situation also led to confusion in the public mind over which group, the Coalition or PrairieFire, was involved in a particular activity. $)^{39}$

The Coalition, unlike its counterpart in Wisconsin and many other new groups that emerged in the 1980s, was not a membership organization. In Iowa, while the NFO and NFU were willing to participate, neither wanted yet another rival group out there vying with them for members. At meetings, literature

38. Ostendorf interview; Glass interview; Swoboda interview.

39. Ostendorf interview; George Naylor, telephone interview with author, February 1994. Ostendorf said that he and Sorteberg became the staff because they did not have to farm. Sorteberg's layoff at the height of the farm crisis speaks volumes about the FU in this era. He was the Iowa Farmers Union's only paid staff person, and his salary was subsidized by the national organization. In the early and mid-1980s, however, the FU was faced with a severe financial crisis, and among its budget cuts was the Iowa subsidy. Sorteberg was an effective organizer and spokesperson, and his departure was a real loss to both the FU and the Coalition. Later, however, the FU in Iowa underwent a revival of sorts. Gary Lamb, a former AAM leader who was active in the Iowa Farm Unity Coalition, was elected state FU president. Dixon Terry, after a break with the USFA, also joined the FU. At the time of his death in 1989, Terry was the vice-president of the Iowa organization. 
and membership applications from constituent groups were often made available, and Coalition organizers deferred to particular organizational sensibilities, such as NFO's commitment to collective bargaining. Funding was a major problem for the Coalition, as each constituent group paid only $\$ 100$ annual dues. Although separate memberships were not possible, individual subscriptions to the Farm Unity News were solicited at $\$ 10$ a year. ${ }^{40}$

The farm insurgents of the 1980s tried to attract support from other groups. "Farmer-labor" movements have had a special place in the imagination of some people for more than a century. Yet, with the exception of a few cases such as the Minnesota Farmer-Labor Party, they have proven difficult to sustain. ${ }^{41}$ In the 1980s, however, there was considerable cooperation between some farm groups and some unions. The United Automobile Workers (UAW), through its Community Action Program, joined the Iowa Farm Unity Coalition, and its members supported the farm movement in Iowa, Illinois, and Minnesota. Occasionally, the farm movement and the United Food and Commercial Workers supported one another's efforts. Finally, farmers turned out to back the P-9 strikers in Austin. ${ }^{42}$

40. Ostendorf interview; Naylor interview; Hodne interview. Iowa NFO president Dick Steffen, like Gary Lamb, was also a strong supporter of the Iowa Farm Unity Coalition. See also note 39.

41. See Hugh T. Lovin, "The Persistence of Third Party Dreams in the American Labor Movement, 1930-1938," Mid-America (1976), 141-57; Richard M. Valelly, Radicalism in the States: The Minnesota Farmer-Labor Party and the American Political Economy (Chicago, 1989). For a brief popular account on the history of farmer-labor efforts, see Bill Pratt, "Farmer-Labor Cooperation in the Midwest," U.S. Farm News, February 1982. This article was based on a talk given at the 1981 USFA convention; it first appeared in the Omaha Labor Chronicle, January 1982. See also Wilson J. Warren, "The 'People's Century' in Iowa: Coalition-Building Among Farm and Labor Organizations, 19451950," Annals of Iowa 49 (1988), 371-93.

42. See Andrew H. Malcolm, "Farmers and Unions Joining to Fight Economic Hardship," New York Times, 5 June 1983. The P-9 strikers resisted demands for wage concessions at Hormel's flagship packing plant in Austin, Minnesota. Although the strike attracted widespread support within the labor movement and among liberal and left-wing well-wishers, the strike ended in defeat. P-9 was placed under a trusteeship by the United Food and Commercial Workers International. See Peter Rachleff, Hard-Pressed in the Heartland: The Hormel Strike and the Future of the Labor Movement (Boston, 1993); and David Hage and Paul 
Rural insurgents of this era also reached out to the peace movement and church groups. In Iowa, Catholic Rural Life joined the Iowa Farm Unity Coalition, and Bishop Maurice Dingman of Des Moines proved to be a solid ally. On occasions such as Farm Crisis Day (October 2, 1982) or the National Crisis Action Rally at Ames (February 27, 1985), the farm movement publicized the diversity of its supporters. ${ }^{43}$ Yet the ranks of the recent insurgency were much thinner than those of its predecessors. ${ }^{44}$

Women played a major role in the farm revolt of the 1980s. Although they had taken part in the historic farm efforts, especially the Farmers Alliance and the Farmers Union, a number of women emerged as leaders in this era. ${ }^{45}$ Bobbi Polzine, Anne

Klauda, No Retreat, No Surrender: Labor's War at Hormel (New York, 1989). In January 1986, a small Groundswell tractorcade drove to Austin to show its support for P-9. Dolores Swoboda noted that this pro-union gesture cost her organization some members. In some cases, farmers who defected wanted jobs in the plant. Other farmers left the organization because they thought that Groundswell should work full-time on the farm crisis. She felt that the labor movement strongly supported farmers in that era and mentioned that there was a UAW representative on the Groundswell board for two or three years. Swoboda interview.

43. Nebraskans for Peace affiliated with NAFA. Merle Hansen, NAFA president, had helped organize this group's predecessor, Rural Nebraskans for Peace. Hansen interview.See also Mark Ritchie, "Farmers and Environmentalists Must Unite," North American Farmer, 30 December 1985. Church groups and individual clergy were very important in the farm movement of the $1980 \mathrm{~s}$. Activists and others often carried white crosses at farm sales and planted them at courthouses or other sites to mark the loss of farms. See Browne, Private Interests, Public Policy, and American Agriculture, 75, 83.

44. Farmers were less than 3 percent of the population, and the farm crisis of the 1980s did not threaten everyone in the countryside. Those who had avoided increased indebtedness in the previous decade often were in a good financial position and unsupportive of their less fortunate neighbors.

45. Historical research on women in farm movements is limited. See Julie Roy Jeffrey, "Women in the Southern Farmers' Alliance: A Reconsideration of the Role and Status of Women in the Late Nineteenth-Century South," Feminist Studies 3 (Fall 1975), 72-91; Karen Starr, "Fighting for a Future: Farm Women of the Nonpartisan League," Minnesota History 48 (Summer 1983), 255-62; Kim E. Nielsen, "We All Leaguers by our House': Women, Suffrage, and Red-Baiting in the National Nonpartisan League," Journal of Women's History 6 (Spring 1994), 31-50; Leslie A. Taylor, "Femininity as Strategy: A Gendered Perspective on the Farmers' Holiday," Annals of Iowa 51 (1992), 252-77; William C. Pratt, "Women in the Farm Revolt of the 1930s," Agricultural History 67 
Kanten, and Dolores Swoboda were highly visible in Minnesota. Carol Hodne served as director of NAFA; Denise O'Brien was a key figure in the Iowa Farm Unity Coalition and later served as president of the National Family Farm Coalition in 1994 and $1995 .^{46}$ This time, certain jobs were not automatically reserved for women as often seemed to have been the case in the Farmers Union. Moreover, there were efforts to address women's concerns. Although its impact should not be exaggerated, the women's movement arrived in rural America during the 1980s. Articles appeared in the farm movement press, and conferences and caucuses were organized, all dealing with rural women's topics. ${ }^{47}$ Recently, Mark Friedberger has argued that women defined the insurgency in Iowa. According to his analysis, they did much of the work and encouraged practices (such as mediation of disputes with creditors) that were characteristically feminine. Some may argue with a point here and there, but Friedberger's study confirms that women were major players

(Spring 1993), 214-23; Linda G. Ford, "Another Double Burden: Farm Women and Agrarian Activism in Depression-Era New York State," New York History 75 (October 1994), 373-96.

46. For Polzine, Kling, and Kantor, see Schwab, Raise Less Corn and More Hell, 135-44, 203-18. For O'Brien, see Jerry Perkins, "Activism Takes Iowa Woman to Top of Farm Group," Des Moines Register, 6 March 1994; and Kristi Wright, "Not Afraid to Go Her Own Way," Omaha World-Herald, 1 October 1995. Hodne was named to Esquire magazine's 1985 list of "Men and Women Under 40 Who Are Changing the Nation," North American Farmer, 30 December 1985.

47. The Wisconsin Farm Unity Coalition held a women's conference in 1984, and "Harvest our Potential: A Rural Women's Gathering" has been held in Des Moines almost every year since 1986. See North American Farmer, 26 June 1984; Alynne Romo, "Conference Aids Women Organizing for Progressive Social Change," ibid., June 1988; Carol Smith, "Common Ground' Explored by Rural Women," ibid., March 1989. For articles on women's themes, see Denise O'Brien, "Farm Women and Economic Discrimination," ibid., 27 June 1984; Clara Jorgensen, "Women Farm Activists in History," ibid. 26 July 1984; Carol Hodne, "Women's Strategic Role in the Farm Movements," ibid., January 1989. NAFA women organized a caucus called the Red Bandanna Brigade. See The Scarlet Letter (undated) and Holding Our Ground: Farm Women Fight Back (February 1988), two NAFA collections of newspapers and magazines related to the farm crisis. (These items and other materials, including a number of issues of the North American Farmer, were loaned to me by Carol Hodne.) 
in the farm movement of the past decade. ${ }^{48}$ Despite the prominence of some women in the farm insurgency, one should not assume that there was equal opportunity for women to advance to leadership roles. A number of them did, but older attitudes and the traditional division of labor on the farm often remained obstacles to women's full participation in the movement. ${ }^{49}$

Rural activists made a real effort to reach out to farmers in other parts of the world. In the early 1980s they learned that many Canadian farmers were in a similar economic predicament and that a parallel protest movement was emerging north of the border. Subsequently, personal and organizational ties developed between the two insurgencies. A key Canadian figure, Terry Pugh, worked with NAFA; the National Farmers Union of Canada and the Canadian Farmers Survival Association were affiliated with NAFA at times. ${ }^{50}$ Organizers also developed ties with groups in western Europe and Central America. When Gary Hart spoke to the 1983 USFA convention, a Dutch activist in the audience voiced his dissent. A number of insurgents traveled

48. Mark Friedberger, "Women Advocates in the Iowa Farm Crisis of the 1980s," Agricultural History 67 (Spring 1993), 224-34. Friedberger may have overlooked historic precedent for some of the practices that he felt were new departures. For example, mediation was used by the Farmers' Holiday in the 1930s. See Dyson, "The Farm Holiday," 127-34. For example, "Throughout that winter [1932-33], front page headlines told of farmers halting foreclosure sales, but the quiet work of the councils of defense in heading off those incidents should have provided the real drama for a perceptive reporter." Ibid., 131. Dave Ostendorf also mentioned that mediation was something they learned about from the history of the 1930s. Ostendorf interview.

49. John Faragher's observations on nineteenth-century rural life still have some relevance today: "Men were free to pursue the work of the public world precisely because the inequitable division of labor at home made them beneficiaries of women's and children's labor. ... [T] o be sure, farming was hard work for all. But farmers have always been palpably freer than farm wives from work around the farm and granted the prerogative of social participation, participation that took place while their women were home working with children, chickens, and cows." John Mack Faragher, "History from the Inside-Out: Writing the History of Women in Rural America," American Quarterly 33 (Winter 1981), 550.

50. Ritchie interview. See Terry Pugh, ed., Fighting the Farm Crisis (Saskatoon, Saskatchewan, 1987); Terry Pugh, "Protest Targets Crisis in Rural Canada," North American Farmer, June 1988. NAFA had three Canadian affiliates in 1985. Ibid., 30 December 1985. 
to Central America, Europe, and Asia to express their solidarity with family farmers around the world. Foreign policy concerns, especially in regard to Latin America, explained some of this international focus. Many farm activists of the 1980s sought to link farm and peace issues; they were as opposed to the ReaganBush positions on foreign policy as they were to those on agriculture. ${ }^{51}$ Yet the extent of such linkage should not be exaggerated. Most farmers who took part in the insurgency were preoccupied with problems closer to home.

One serious problem closer to home was the growth of rightwing extremism in the countryside. By the mid-1980s, some farm activists became alarmed at its strength. PrairieFire and other groups launched a counteroffensive, conducting workshops and exposing the activities of far-right activists. ${ }^{52}$ But there was no consensus within the farm movement on how to deal with antiSemitism and other extremist views. Some groups, such as NAFA, had a different approach from that of PrairieFire, in part because they were attempting to wean farmers away from the far right. When Jesse Jackson spoke in western Kansas in 1983, there reportedly were many members of the Posse Comitatus in the audience. Jackson's involvement lessened white racism in the countryside in the 1980s. But extremists were able to recruit farmers into far-right groups, and anti-Semitism increased in many locales, at least for a time..$^{53}$

51. Carol Hodne recently quipped that "We were the peaceniks of the farm movement." Hodne interview.

52. Ostendorf interview; Levitas interview. See also Crystal Nix, "Extremists in Farm Belt Are Assailed," New York Times, 21 September 1985.

53. Hodne interview; Hansen interview. This essay is not the place to discuss right-wing extremism in the countryside during the 1980s and thereafter, but it deserves more attention. There were differences among activists concerning how the farm movement should have responded to the far right. PrairieFire came to see the exposure of right-wing extremism as one of its major tasks and was disappointed when other rural activists did not follow suit. Ostendorf interview. Browne observed: "Direct opposition to the radical right, however, was often left to be articulated by nonfarm movement leaders who were not in the difficult position of criticizing cohorts." Browne, "Challenging Industrialization," 20. 
DESPITE THEIR RHETORIC, and that of the press on occasion, farm activists in this era had to face issues that their counterparts in the past had not. Times had changed, and so had some of the issues. When comparing recent rural activism with that of earlier eras, there is one striking similarity, however: both bought time for some farmers. ${ }^{54}$ In the 1930s or more recently, that was no small achievement.

The farm revolt of the 1980s itself became history before the end of the decade. Like the earlier rural causes from which it had drawn ideas and inspiration, this insurgency was relatively short-lived. But for a moment it stood center stage in the farm belt, dramatizing the plight of hard-pressed family farmers, many of whom it had drawn to its neopopulist banner. A number of activists had enlisted the history of earlier farm movements to their cause, and films and speakers stirred memories and imaginations with accounts of protest and penny auctions. The new groups sometimes seemed to follow an earlier script, but a closer look at their activities reveals numerous innovations or departures as well. Some activists knew or learned how to deal with the media and raise money; some saw the need for new approaches in many areas, including counseling, legal action, and coalition building. The participants of this insurgency themselves were not carbon copies of earlier farm activists. Nonfarm people and especially women played a big role in this era. ${ }^{55}$ Most of the activists of the 1980 s knew that history does

54. Sarah Vogel recently observed that the injunction in Coleman v. Block "bought time" for farmers. Vogel interview. But that also was the case for other activities that were part of the insurgency of the 1980s.

55. Sarah Vogel also noted that quite a few key people in the recent farm movement were "townies" or women, or in her case, both. Vogel interview. Some of the activists were part of a "movement culture" broader than that of the farm movement. To them, at least in some respects, movements for social change were virtually interchangeable, all part of their struggle for a better world. They seemed as at home in New York or Washington as they were in Mason City or Greenfield, Iowa. In making these observations, I am not suggesting a lack of sincerity or commitment on their part. (Levitas, for example, lived in a house without plumbing for two years, in Greenfield, Iowa, and milked cows for Dixon Terry every morning before he drove to Des Moines to the Rural America office. Levitas interview. See also Jerry Perkins, "A Youthful New Yorker Learns to Milk, 'Articulate' Strapped Farmers' Woes," Des Moines Register, 26 December 1982.) But these activists were not farmers 
not repeat itself. They drew on the historical record, to be sure, but they also created a history of their own. If all they had done was try to reenact the past, their efforts would have amounted to a footnote rather than a new chapter in the history of farm movements. $^{56}$

and could easily fit into other causes; indeed, they often have. Mark Ritchie, for example, had experience in food co-ops and the Nestle boycott, played a key role in the USFA effort in the early 1980s, and helped organize the lowa Farm Unity Coalition, NAFA, the League of Rural Voters, and the National Save the Family Farm Coalition. For the last several years, he has headed the Minneapolis-based Institute of Food and Trade Policy and is an outspoken critic of the North American Free Trade Agreement (NAFTA) and the General Agreement on Tariffs and Trade (GATT). A recent speaker at a globalization forum held at Columbia University called Ritchie "the Paul Revere of the emerging [anti-globalization] movement." Jay Walljasper, "The Price of Thinking Globally," Minneapolis Star Tribune, 30 November 1995. Danny Levitas left PrairieFire in 1989, served as director of the Center for Democratic Renewal in Atlanta for several years, then became an independent fund-raiser for groups such as PrairieFire and the Institute of Food and Trade Policy. He now is working on a book dealing with the contemporary far right. In 1993 Dave Ostendorf stepped down as director of PrairieFire and moved to the Chicago area, where he has undertaken an initiative on issues affecting both rural and urban communities. Carol Hodne, who had been raised on a farm, left NAFA in 1989 and enrolled in graduate school at the University of Iowa. A number of key people who had been farmers are no longer involved in rural efforts. Dixon Terry, Tom Saunders, and Darrell Ringer died at a young age in the late 1980s. Others have left farming. Denise O'Brien, a long-time Iowa Farm Unity Coalition activist, a former PrairieFire board member and staff person, and most recently president of the National Family Farm Coalition, stopped full-time farming in 1995. Her husband took a job off the farm and they leased their dairy herd to another farmer. See Lisa Anderson, "America's Small Family Farms Face a Grim Harvest," Chicago Tribune, 2 July 1995.

56. Many of the organizations that emerged in the 1980s either no longer exist or have very limited activity. Even PrairieFire, one of the most established of the new groups, recently cut its staff due to funding problems. See Jerry Perkins, "PrairieFire Cutting Staff as Projects Come to End," Des Moines Register, 15 December 1995. Reluctant as I am to say it, the 1980 s may have witnessed the last significant progressive rural insurgency in American history. That, of course, does not mean that all rural and farm organizations will disappear. For a more optimistic prognosis, see Mooney and Majka, Farmers' and Farm Workers' Movements. 
Copyright of Annals of Iowa is the property of State of Iowa, by \& through the State Historical Society of Iowa and its content may not be copied or emailed to multiple sites or posted to a listserv without the copyright holder's express written permission. However, users may print, download, or email articles for individual use. 